\title{
FEEDING INTERACTION OF THE NON-NATIVE AFRICAN CATFISH (Clarias gariepinus BURCHELL, 1822) IN ITANHÉM RIVER ESTUARY, BAHIA, BRAZIL
}

\author{
Leandro Bonesi Rabelo* and Lucy Satiko Hashimoto Soares \\ Instituto Oceanográfico da Universidade de São Paulo \\ (Praça do Oceanográfico, 191, 05508-120 São Paulo, SP, Brasil)
}

*Corresponding author: lbrabelo@yahoo.com.br

http://dx.doi.org/10.1590/S1679-87592014051406203

\begin{abstract}
A B S T R A C T
A total of 214 stomachs of Clarias gariepinus, Centropomus undecimalis and C. parallelus from the Itanhém and Caravelas Rivers, northeastern Brazil, were analyzed to investigate the impact of the non-native species Clarias gariepinus on the Itanhém River food web as compared to that of the adjacent Caravelas River, where this species has not been registered. In Itanhém River, shrimp was the most important food for C. gariepinus, and Teleostei for C. parallelus. In the Caravelas River, Brachyura was the main food item for $C$. parallelus, and Teleostei for $C$. undecimalis. There was no food overlap between the species within or between rivers. There is no evidence, in the results of this study, of changes in the diet of the Centropomus parallelus due to the presence of the non-native species.
\end{abstract}

\section{RES UMO}

Foram analisados 214 estômagos de Clarias gariepinus, Centropomus undecimalis e $C$. parallelus do rio Itanhém e rio Caravelas, nordeste do Brasil, com a finalidade de investigar o impacto da espécie exótica Clarias gariepinus sobre a trama trófica do Rio Itanhém, tendo como referência a alimentação das espécies nativas no Rio Caravelas. No Rio Itanhém, os camarões foram mais importantes na alimentação de Clarias gariepinus (55\%), enquanto Teleostei $(98,1 \%)$ foi para $C$. parallelus. Brachyura compôs $92,8 \%$ da dieta de C. parallelus do rio Caravelas, enquanto que para C. undecimalis, Teleostei compôs $72,5 \%$. Não houve sobreposição alimentar em nenhum dos casos estudados. Pelos resultados desse trabalho não foi possível detectar indícios de mudanças na dieta de C. parallelus do Rio Itanhém.

Descriptors: Clarias gariepinus, Centropomus, Non-native species, Diet, Northeast, Brazil. Descritores: Clarias gariepinus, Centropomus, Espécie exótica, Dieta, Nordeste, Brasil.

\section{INTRODUCTION}

Non-native species are naturally continuously transported, though at a low rate, in a given region. The invasion by and increase in the number of transported species has been speeded up by human activity (McKINNEY; LOCKWOOD, 1999; VALIELA, 2006).

The most significant transport of exotic species occurs as a result of navigation, and secondly of mariculture which in some cases introduces species unacceptable to the local market. These species are then discharged into the natural environment, either intentionally or accidentally (VALIELA, 2006).
The successful invasion of non-native fish species can affect the structure and functioning of aquatic communities (LODGE, 1993). Predation by the invasive species is one of the main kinds of interaction that can lead to a reduction in the abundance of prey or native species (ZARET; PAINE, 1973; LATINI; PETRERE Jr., 2004).

The African catfish Clarias gariepinus is a freshwater species of widespread occurrence in calm lakes, streams and marshes, both in shallow and deep water in Africa, as well as in the Middle East and Turkey (TEUGELS, 1982). In natural environments, the reproduction of $C$. gariepinus is associated with the rainy season (YALÇIN ET AL., 2001a), and 
individuals can reach up to $1.5 \mathrm{~m}$ in total length (HERREL ET AL., 2005).

The food spectrum of the species is broad in natural environments, being composed of arthropods, mollusks, fish, reptiles, amphibians and plants (BRUTON, 1979; YALÇIN ET AL., 2001b).Toleration of large environmental variation, e.g. of temperature and dissolved oxygen, leads to rapid acclimation to new environments.

The wide prey spectrum, associated with its ability to adapt to different ecosystems, its fast growth and air breathing capability, partly explains the wide dispersal area of $C$. gariepinus. In Brazil, this fish has become established in several rivers and lakes in the Southern, Southeastern and Northeastern regions (VITULE ET AL., 2006; ROCHA, 2008).

There are reports from the states of Bahia and Parana that the capture of the African catfish is frequent and this has been associated with the consequent decline of certain native species (VITULE ET AL., 2006).

In the state of Bahia, catches of the African catfish have been observed in the Itanhém River estuary, and the decline of snook (Centropomus undecimalis and C. parallelus) has also been reported. However, in the adjacent Caravelas River estuary, there have been no reports of catches of this nonnative species.
This study was conducted, in the light of this information, to investigate the occurrence of African catfish in both estuaries, and to verify the possible occurrence of diet overlap between Clarias gariepinus and Centropomus species.

\section{Material and Methods}

$$
\text { Study Area and Sampling }
$$

Fish were caught in the Caravelas (CAR) and Itanhém (ITA) River estuaries, located between latitudes $17^{\circ} 30^{\prime} \mathrm{S}$ and $18^{\circ} \mathrm{S}$, and longitudes $39^{\circ} 10^{\prime} \mathrm{W}$ and $39^{\circ} 20^{\prime} \mathrm{W}$ (Fig. 1) in June/07, February/08, April/08, June/08, August/08, and March/09.

According to PEREIRA ET AL. (2010), the Caravelas River estuary is well mixed, being mainly controlled by tidal currents. The hydrodynamic structure of the Itanhém River estuary is more variable. During spring tides there is vertical homogeneity and during neap tides a strong stratification (SCHETTINI ET AL., 2008).

Fish were captured by purse seine, locally named "camboa" and gillnets, between midnight and 5 a.m. Specimens were measured (total and standard length, $\mathrm{mm}$ ) and weighed (total and eviscerated weight, g), and their digestive tracts removed and fixed in $10 \%$ buffered formalin.

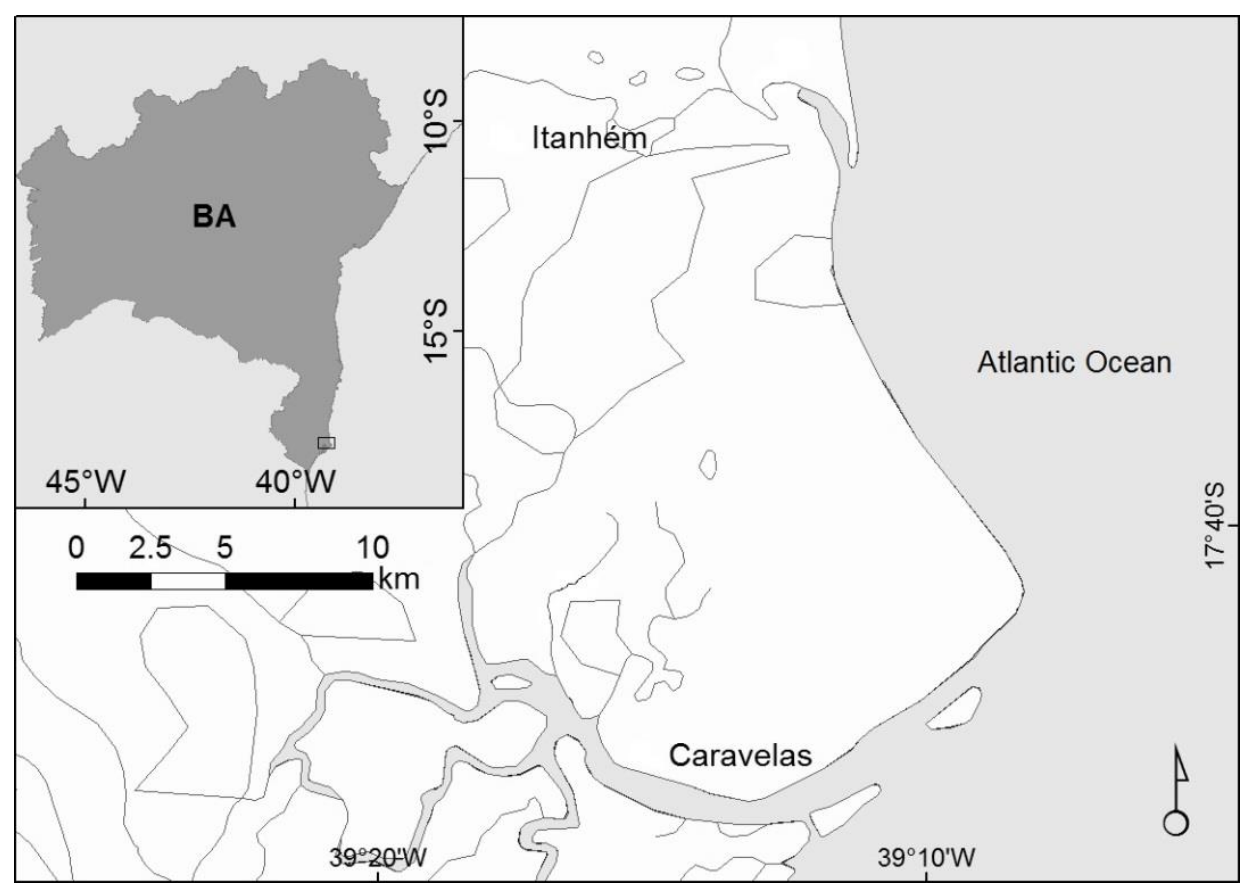

Fig. 1. Study area showing Caravelas and Itanhém estuaries. 


\section{Stomach Content Analysis}

Food items were identified to the lowest possible taxon, often to species level. The following identification keys were used: Teleostei (FIGUEIREDO; MENEZES, 1978, 1980; MENEZES; FIGUEIREDO, 1980, 1985; ESCHMEYER, 2009; CARPENTER, 2002), Decapoda (WILLIAMS, 1984; MELO, 1996), and Isopoda (SCHULTZ, 1969).

The frequency of occurrence $(\mathrm{O}$, percentage of stomachs containing a given prey), number $(\mathrm{N}$, percentage of a given prey in relation to total number of prey items in the sample) and weight (W, percentage weight of a prey item in the total weight of all the prey in the sample) of each category of prey were calculated in accordance with Hyslop (1980). Then the index of relative importance (PINKAS ET AL., 1971) was calculated with the equation: IRI = 100. O $(\mathrm{N}+\mathrm{W}) / \sum[\mathrm{O}(\mathrm{N}+\mathrm{W})]$.

The diet overlap between species was calculated with Schoener's index (SCHOENER, 1968; LINTON ET AL., 1981; KREBS, 1999) following the formula: $\alpha=1-1 / 2\left(\sum\left|\mathrm{P}_{\mathrm{ia}}-\mathrm{P}_{\mathrm{ib}}\right|\right)$, where $\mathrm{P}_{\mathrm{ia}}$ and $\mathrm{P}_{\mathrm{ib}}$ are proportions for species $a$ and $b$, respectively, for $i t h$ prey category.

Schoener's index values range from zero (completely different diets) to one (identical diets). $\alpha$ values over 0.6 can be considered to represent a high overlap diet (WALLACE Jr., 1981; WALLACE Jr.; RAMSEY, 1983). For overlap analysis, the calculation was undertaken using the IRI.

The graphical representation of AMUNDSEN ET AL. (1996), which aims to ascertain the importance of feeding strategies and prey in a predator's diet, was used. This method consists of plotting the frequency of occurrence data on abscissa and prey-specific abundance $\left(\mathrm{Pi}=100 .\left(\sum \mathrm{Si} / \sum \mathrm{St}\right)\right)$ on ordinate, where $\mathrm{Si}$ is the bulk of (volume, weight or number) prey $i$ and St is the number of stomachs in which prey $i$ was registered. The number of prey items was used in this study.

\section{RESULTS}

A total of 123 specimens of $C$. parallelus and 68 of $C$. undecimalis were caught in Caravelas
River (CAR); and 102 specimens of $C$. parallelus and 78 Clarias gariepinus in Itanhém River (ITA). Stomach contents with identifiable items were used for this study, as shown in Table 1.

In CAR, a total of 27 prey categories were registered in stomachs of $C$. parallelus, the crab Aratus pisonii being the most important (62.3\%). For C. undecimalis, among 25 items unidentified Teleostei was the most important (42.5\%) (Table 2).

In ITA, stomach contents of $C$. parallelus presented 18 items, the fish Anchoviella lepidentostole being the most important item (67.8\%). Clarias gariepinus had 16 prey categories, showing predominance of the unidentified shrimp Caridea $(67.6 \%)$ (Table 2).

Table 2 gives a detailed list of food categories and Fig. 02, a pooled plot of the same. Teleostei presented the highest occurrence for $C$. parallelus $(91.7 \%)$ and shrimp for Clarias gariepinus $(68.2 \%)$, in ITA. Brachyura $(84.5 \%)$ and Teleostei $(69.2 \%)$ were the main categories of $C$. parallelus and C. undecimalis in CAR, respectively.

Although Brachyura represented the most important prey item (IRI $=92.8 \%$ ) for $C$. parallelus in CAR, it was less important (IRI $=19.6 \%$ ) for $C$. undecimalis. In ITA, the most important item for $C$. gariepinus was shrimp (IRI $=55 \%$ ), while for $C$. parallelus it was Teleostei (IRI $=98.1 \%$ ) (Fig. 3).

The graphical representation of Amundsen ET AL. (1996) for C. parallelus in CAR (Fig. 04A) showed a high frequency of occurrence and high preyspecific abundance for Brachyura, indicating specialization in that category. There is an indication that almost all individuals feed on the dominant prey category. Small proportions of other categories were occasionally included in the diet of some specimens. A similar feeding strategy pattern was shown for that fish species in ITA (Fig. 4C), but the main prey was Teleostei.

C. undecimalis from CAR did not show the same clear pattern as its congener species (Fig. 4A and 4B), but there is a tendency to food specialization in Teleostei and Brachyura. Although Stomapoda has shown high prey-specific abundance, few predators are specialized in that prey category.

Table 1 . Number, size range and percentage of analyzed stomachs by species by location.

\begin{tabular}{llllllll}
\hline \hline Location & Species & $\mathrm{N}$ & \multicolumn{2}{c}{ Size $(\mathrm{mm})$} & \multicolumn{2}{c}{ Stomachs (\%) } \\
\cline { 5 - 8 } & & & Minimum & Maximum & Empty & Analyzed \\
\hline Caravelas River & C. parallelus & 123 & 200 & 515 & 31.7 & 68.3 \\
& C. undecimalis & 68 & 245 & 830 & 44.1 & 55.9 \\
\multirow{3}{*}{ Itanhém River } & C. parallelus & 102 & 240 & 490 & 52.9 & 47.1 \\
& Clarias gariepinus & 78 & 310 & 780 & 43.6 & 56.4
\end{tabular}


Table 2. Frequency of occurrence $\left(\mathrm{O}_{\%}\right)$, number $\left(\mathrm{N}_{\%}\right)$ and weight $\left(\mathrm{W}_{\%}\right)$ and Index of Relative Importance (IRI $\left.\%\right)$ of food items of Clarias gariepinus, Centropomus parallelus and $C$. undecimalis by location.

\begin{tabular}{|c|c|c|c|c|c|c|c|c|c|c|c|c|c|c|c|c|}
\hline \multirow[t]{3}{*}{ Food items } & \multicolumn{8}{|c|}{ Caravelas River } & \multicolumn{8}{|c|}{ Itanhém River } \\
\hline & \multicolumn{4}{|c|}{$\begin{array}{l}\text { Centropomus parallelus } \\
\qquad(\mathrm{n}=84)\end{array}$} & \multicolumn{4}{|c|}{$\begin{array}{l}\text { Centropomus undecimalis } \\
(\mathrm{n}=38)\end{array}$} & \multicolumn{4}{|c|}{$\begin{array}{l}\text { Centropomus parallelus } \\
\qquad(\mathrm{n}=48)\end{array}$} & \multicolumn{4}{|c|}{$\begin{array}{l}\text { Clarias gariepinus } \\
(\mathrm{n}=44)\end{array}$} \\
\hline & $\mathrm{O}$ & $\mathrm{N}$ & W & IRI & $\mathrm{O}$ & $\mathrm{N}$ & $\mathrm{W}$ & IRI & $\mathrm{O}$ & $\mathrm{N}$ & W & IRI & $\mathrm{O}$ & $\mathrm{N}$ & $\mathrm{W}$ & IRI \\
\hline Insecta un. & & & & & 2.6 & 1.3 & & 0.1 & 2.1 & 1.0 & & - & 43.2 & 8.5 & 0.7 & 5.2 \\
\hline Gastropoda & & & & & & & & & & & & & 38.6 & 30.9 & 0.2 & 15.7 \\
\hline Crustacea un. & & & & & 2.6 & 1.3 & & 0.1 & & & & & 4.5 & 0.4 & 0.5 & 0.1 \\
\hline Stomatopoda & & & & & 2.6 & 1.3 & 3.0 & 0.5 & & & & & & & & \\
\hline Brachyura un. & 6.0 & 1.3 & 1.1 & 0.2 & 7.7 & 4.0 & & 1.3 & 2.1 & 1.0 & & - & 2.3 & 0.2 & 0.1 & - \\
\hline $\begin{array}{l}\text { Eurytium } \\
\text { limosum }\end{array}$ & 23.8 & 9.4 & 5.1 & 4.6 & 12.8 & 6.7 & 0.5 & 3.9 & & & & & & & & \\
\hline Callinectes sp. & 2.4 & 0.5 & 0.9 & 0.1 & 5.1 & 2.7 & 0.2 & 0.6 & 2.1 & 1.0 & 0.1 & & & & & \\
\hline C. danae & 11.9 & 4.8 & 6.7 & 1.8 & 5.1 & 2.7 & 5.4 & 1.7 & 2.1 & 1.0 & 1.7 & 0.1 & & & & \\
\hline C. larvatus & 2.4 & 0.5 & 0.8 & - & & & & & & & & & & & & \\
\hline $\begin{array}{l}\text { Goniopsis } \\
\text { cruentata }\end{array}$ & 35.7 & 12.6 & 42.6 & 26.4 & 5.1 & 2.7 & 5.1 & 1.7 & & & & & & & & \\
\hline Aratus pisonii & 71.4 & 50.5 & 14.6 & 62.3 & 15.4 & 9.3 & 18.4 & 17.9 & & & & & 9.1 & 0.8 & 0.9 & 0.2 \\
\hline Uca rapax & 4.8 & 1.3 & 1.1 & 0.2 & & & & & & & & & & & & \\
\hline Uca sp. & 1.2 & 0.3 & & - & & & & & & & & & & & & \\
\hline Caridea un. & 2.4 & 0.5 & 0.1 & - & 7.7 & 4.0 & 0.7 & 1.5 & 8.3 & 5.1 & 0.8 & 0.8 & 65.9 & 53.1 & 25.6 & 67.6 \\
\hline Alpheidae un. & 1.2 & 0.3 & & - & 10.3 & 5.3 & 0.3 & 2.4 & & & & & & & & \\
\hline $\begin{array}{l}\text { Alpheus } \\
\text { armillatus }\end{array}$ & 6.0 & 1.6 & 0.3 & 0.1 & 5.1 & 2.7 & 0.2 & 0.6 & & & & & & & & \\
\hline $\begin{array}{l}\text { Macrobrachium } \\
\text { acanthurus }\end{array}$ & & & & & & & & & 6.3 & 3.1 & 7.0 & 1.0 & & & & \\
\hline Peneidea un. & 16.7 & 4.8 & 0.2 & 1.1 & 7.7 & 4.0 & 0.1 & 1.3 & 2.1 & 1.0 & & - & 2.3 & 0.8 & 1.1 & 0.1 \\
\hline $\begin{array}{l}\text { Farfantepenaeus } \\
\text { brasiliensis }\end{array}$ & 2.4 & 0.8 & 0.1 & - & 7.7 & 5.3 & 0.5 & 1.9 & & & & & & & & \\
\hline $\begin{array}{l}\text { Xiphopenaeus } \\
\text { kroyeri }\end{array}$ & 1.2 & 0.3 & 0.4 & - & 2.6 & 1.3 & 0.1 & 0.2 & & & & & & & & \\
\hline Isopoda un. & 2.4 & 0.5 & & - & & & & & & & & & 2.3 & 0.2 & & - \\
\hline $\begin{array}{l}\text { Sphaeroma } \\
\text { destructor }\end{array}$ & 3.6 & 0.8 & & - & & & & & & & & & & & & \\
\hline Polychaeta un. & 1.2 & 0.5 & 0.1 & - & & & & & & & & & & & & \\
\hline Teleostei un. & 8.3 & 2.2 & 0.6 & 0.3 & 38.5 & 22.7 & 3.6 & 42.5 & 41.7 & 26.5 & 12.4 & 26.5 & 15.9 & 1.5 & 3.9 & 1.1 \\
\hline Atherinidae & & & & & 2.6 & 1.3 & 0.3 & 0.2 & & & & & & & & \\
\hline Engraulidae & & & & & 7.7 & 4.0 & 2.8 & 2.2 & 4.2 & 2.0 & 0.7 & 0.2 & & & & \\
\hline $\begin{array}{l}\text { Anchoviella } \\
\text { lepidentostole }\end{array}$ & 8.3 & 4.0 & 18.0 & 2.5 & & & & & 41.7 & 44.9 & 54.7 & 67.8 & & & & \\
\hline Siluriformes & & & & & & & & & 2.1 & 2.0 & 0.4 & 0.1 & 4.5 & 0.4 & 0.1 & - \\
\hline $\begin{array}{l}\text { Clarias } \\
\text { gariepinus }\end{array}$ & & & & & & & & & 4.2 & 2.0 & 1.3 & 0.2 & 11.4 & 1.5 & 28.0 & 4.4 \\
\hline Ariidae & & & & & & & & & 2.1 & 1.0 & 2.8 & 0.1 & 4.5 & 1.0 & 3.2 & 0.3 \\
\hline C. parallelus & 1.2 & 0.3 & - & - & 2.6 & 1.3 & 31.9 & 3.6 & & & & & & & & \\
\hline Cichlidae & & & & & & & & & 8.3 & 6.1 & 14.2 & 2.8 & 2.3 & 0.4 & 19.0 & 0.6 \\
\hline Hoplias sp. & & & & & & & & & 2.1 & 1.0 & 3.6 & 0.2 & 2.3 & 0.2 & 9.7 & 0.3 \\
\hline Gerreidae & & & & & 2.6 & 1.3 & 0.2 & 0.2 & & & & & & & & \\
\hline $\begin{array}{l}\text { Diapterus } \\
\text { auratus }\end{array}$ & & & & & 5.1 & 2.7 & 2.1 & 1.0 & & & & & & & & \\
\hline Eucinostomus sp. & 1.2 & 0.3 & 0.1 & - & & & & & & & & & & & & \\
\hline Sciaenidae & & & & & 2.6 & 1.3 & 2.2 & 0.4 & & & & & & & & \\
\hline Stellifer rastrifer & 1.2 & 0.3 & 4.5 & 0.1 & & & & & & & & & & & & \\
\hline Gobiidae & 2.4 & 0.8 & 0.3 & - & 10.3 & 5.3 & 5.4 & 4.6 & 2.1 & 1.0 & & - & & & & \\
\hline $\begin{array}{l}\text { Bathygobius } \\
\text { soporator }\end{array}$ & 2.4 & 0.5 & 2.2 & 0.1 & 10.3 & 5.3 & 17.0 & 9.6 & & & & & & & & \\
\hline Sediment & 1.2 & & 0.1 & - & & & & & 2.1 & & & & 6.8 & & 0.3 & - \\
\hline Vegetable O.M. & 13.1 & & 0.2 & - & 5.1 & & 0.1 & - & 10.4 & & 0.3 & 0.1 & 52.3 & & 6.7 & 4.5 \\
\hline
\end{tabular}

Note: n: number of stomachs; un.: unidentified; “.” insignificant value $(<0.1)$.

It was seen, in relation to the inter-specific analysis in ITA (Fig. 4C - C. parallelus and 4D Clarias gariepinus), that the prey-specific abundance of shrimp is similar, indicating that in specimens of both species in which shrimp occur, the percentage is equivalent. However, the frequency of occurrence is higher for $C$. gariepinus, indicating that many predators are feeding on that category, and low for $C$. parallelus, demonstrating that few individuals of this species are preying on that item. Further, the distribution pattern is different, with the majority of prey items of $C$. gariepinus plotted below $50 \%$ preyspecific abundance, indicating a generalized feeding strategy, while the opposite occurs with $C$. parallelus, indicating a specialized feeding strategy. 

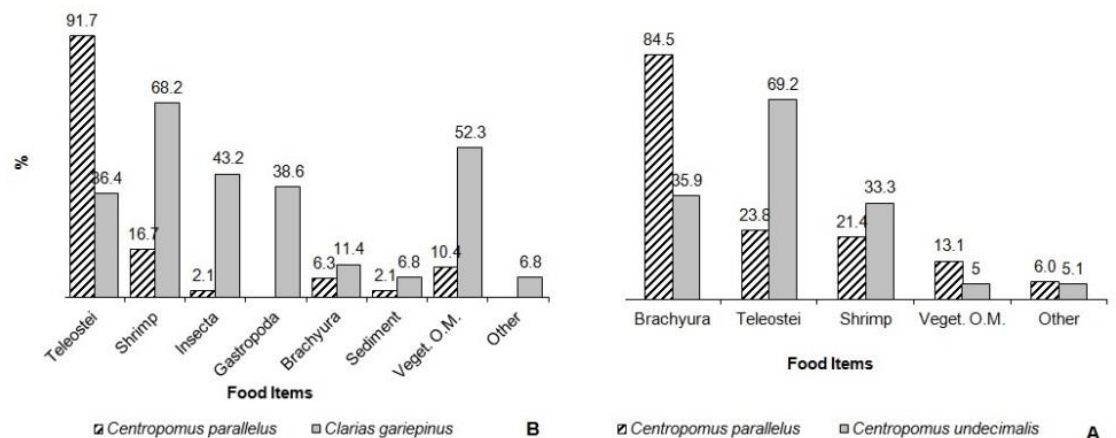

Fig. 2. Frequency of occurrence $\left(\mathrm{O}_{\%}\right)$ of grouped food items of Centropomus parallelus, Centropomus undecimalis, and Clarias gariepinus in: A) Caravelas River and B) Itanhém River.

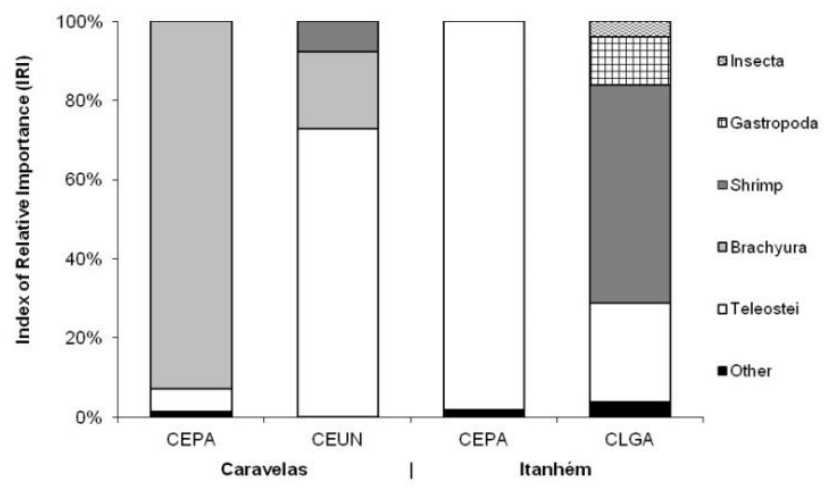

Fig. 3. Index of Relative Importance (IRI $\mathrm{I}_{\%}$ of food items of Centropomus parallelus (CEPA), Centropomus undecimalis (CEUN), and Clarias gariepinus (CLGA) from Caravelas and Itanhém Rivers.

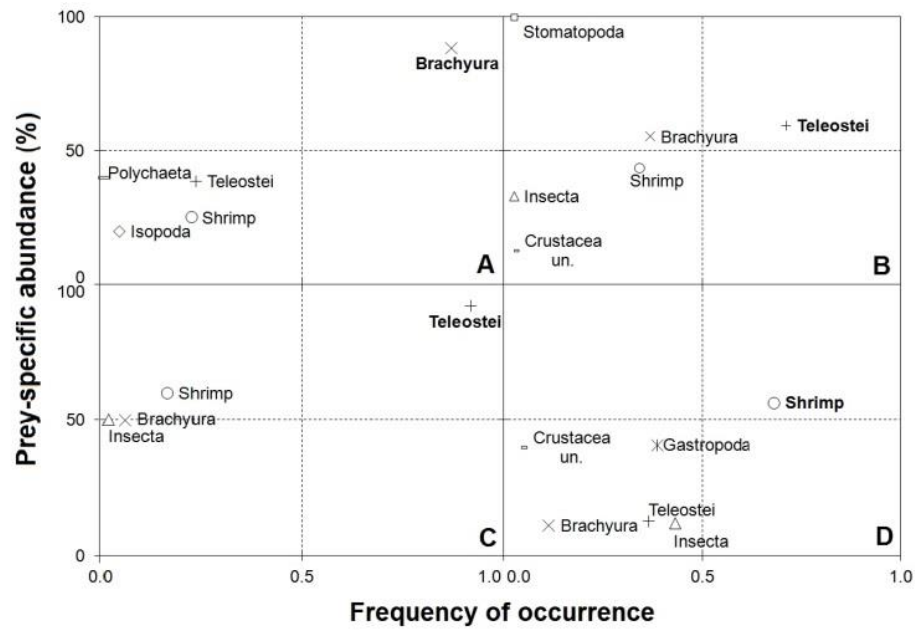

Fig. 4. Food items plotted according to Amundsen, Gabler and Staldvik (1996) graphical representation for A) Centropomus parallelus, B) Centropomus undecimalis from Caravelas River, and C) Centropomus parallelus, and D) Clarias gariepinus from Itanhém River. Names in bold are the most important items in the diet of each species. 
There was a low diet overlap between $C$. undecimalis and $C$. parallelus from CAR $(\alpha=0.273)$. The diets of $C$. gariepinus and $C$. parallelus from ITA ( $\alpha=0.032$ ) were different as well. And the diet overlap between $C$. parallelus from ITA and CAR $(\alpha$ $=0.031)$ was also low.

\section{DisCUSSION}

The trophic ecology of fish is an important source of knowledge to provide guidance for the sustainable use of aquatic ecosystems. Such studies can provide basic information for ecosystem models and for fishery evaluation (GASALLA; SOARES, 2001).

The present study was undertaken to investigate the possible impact of a high tropic-level non-native predator on the assumption that this species might impact the natural food web system by establishing a new partitioning of the available food.

Many cases of the successful invasion and establishment of non-native species with the resulting ecological or economic damage of or threat to human health have been reported (CHORNESKY; RANDALL, 2003). A total of 115 species have been found in Brazilian aquatic ecosystems. These species include bacteria (2), phytoplankton (3), macroalgae (10), aquatic macrophytes (6), zooplankton (10), zoobenthos (43) and fish (41), including the subject of the present study, Clarias gariepinus (BRASIL, 2006).

The non-native species $C$. gariepinus was captured only in the Itanhém River estuary, where the fat snook ( $C$. parallelus) is a native predator. Interestingly, it was not captured in the Caravelas River estuary, where the two snook species occur.

In relation to the food habits of snook species, the diet composition of $C$. parallelus was similar to that of other Brazilian regions (fish and crustaceans), but a detailed analysis showed it was different as between the Itanhém River estuary, where this species feeds mainly on fish, and the Caravelas River, where the most important prey was crab. Studying juveniles of $C$. parallelus from a coastal lagoon in southern Bahia, TONINI ET AL. (2007) found fish, followed by crustaceans, as the most important prey categories. CONTENTE ET AL. (2009) identified shrimp as the main food resource of that species in an estuary in northern São Paul state. The presence of a large mangrove area around the Caravelas River estuary could explain the importance of crabs in the diet. No such extensive mangrove area is present around the Itanhém River estuary, thus explaining the lesser importance of crabs as food resources for fat snook. Prey availability could explain the spatial difference in diet composition.
Some authors (ALIAUME ET AL., 1997; TEIXEIRA, 1997) have shown that juveniles of genus Centropomus are opportunists, using abundant prey at each site. Based on our results and on the literature it is clear that the diet composition of these snook species may be associated with the availability of different prey types in the environments.

In the Caravelas River estuary, there was no overlap between the diets of the Centropomus species, due to the different proportions of available prey. Crab was the main prey for Centropomus parallelus, followed by fish, the opposite occurring for $C$. undecimalis.

Studies of the food habits of Clarias gariepinus in natural ecosystems have shown a wide range of prey, including fish, crustaceans, insects, and even some organic vegetable matter (GROENEWALD, 1964; BRUTON, 1979; DÖRGELOH, 1994). Differently, YALÇIN ET AL. (2001b) found that the most abundant prey in stomachs of African catfish were Diptera larvae. And for SCHOONBEE (1969), zooplankton is a more important food than fish for $C$. gariepinus. BRUTON (1979) suggested that African catfish feed on any available prey, which is in line with the results of this study, which indicated shrimp, followed by fish, as the main prey.

According to the results obtained thus far, it may be stated that there was no overlap between the diets of African catfish Clarias gariepinus and fat snook Centropomus parallelus from the Itanhém River estuary, apparently indicating that these two species are sharing available food resources. It may, therefore, be concluded that the food resources of African catfish and fat snook are not a relevant factor of impact in the Itanhém River estuary, in view of the different means of energy transfer used. Sala; BALLESTEROS (1997), studying the spatial and food partitioning of three species of fish in a rocky Mediterranean infralittoral ecosystem, concluded that these species do not compete for two resources concurrently; whenever there was an overlap of resources other resources were shared. SCHOENER (1974) and MACPHERSON (1981) have demonstrated that habitat partitioning is substantially more effective than different feeding habits in preventing overlapping.

The results of this study are examples of spatial diet variability and food partitioning for fish species. Resource availability in estuaries and the coevolution of prey and predators in a variety of micro-habitats may explain this scenario.

In conclusion, we affirm the impossibility of evaluating the evidence of the impact of African catfish in the Itanhém River estuary through the study of the diet composition. 


\section{ACKNOWLEDGEMENTS}

This study is part of the M.Sc. Dissertation of Leandro Bonesi Rabelo (Universidade de São Paulo, Instituto Oceanográfico). It was funded by FAPESP (São Paulo Research Foundation) and supported by Cepene/Ibama Advanced Base Caravelas-BA, and a CNPq scholarship awarded to $\mathrm{L}$. B. R.

\section{REFERENCES}

ALIAUME, C.; ZERBI, A.; MILLER, J. M. Nursery habitat and diet of juvenile Centropomus species in Puerto Rico estuaries. Gulf Mex. Sci., v. 15, n. 2, p. 77-87, 1997.

AMUNDSEN, P. A.; GABLER, H. -M.; STALDVIK, F. J. A new approach to graphical analysis of feeding strategy from stomach content data - modification of the Costello (1990) method. J. Fish Biol., v. 48, n. 4, p. 607-614, 1996.

BRASIL. Ministério do Meio Ambiente. Espécies exóticas invasoras: situação brasileira. Brasília: MMA, 2006. 24 p. (alterei a entrada de autor de IBAMA para Brasil)

BRUTON, M. N. The food and feeding behaviour of Clarias gariepinus (Pisces: Clariidae) in Lake Sibaya, South Africa, with emphasis on its role as a predator of cichlids. Trans. Zool. Soc. London, v. 35, n. 1, p. 47114, 1979.

CARPENTER, K. E. (Ed.). The living marine resources of the Western Central Atlantic. Rome: FAO, 2002. 3 v. (FAO species identification guide for fishery purposes) (Special publication/American Society of Ichthyologists and Herpetologists; n. 5).

CHORNESKY, E. A.; RANDALL, J. M. The threat of invasive alien species to biological diversity: setting a future course. Ann. Mo. Bot. Gard., v. 90, n. 1, p. $67-$ 76, 2003.

CONTENTE, R. F.; STEFANONI, M. F.; GADIG, O. B. F. Size-related shifts in dietary composition of Centropomus parallelus (Perciformes: Centropomidae) in an estuarine ecosystem of the southeastern coast of Brazil. J. Appl. Ichthyol., v. 25, n. 3, p. 335-342, 2009.

DÖRGELOH, W. G. Diet and food selection of Barbus aeneus, Clarias gariepinus and Oncorhynchus mykiss in a clear man-made lake, South Africa. Water SA, v. 20, n. 1, p. 91-98, 1994.

ESCHMEYER, W. (Ed.). Catalog of fishes. San Francisco: California Academy of Sciences, 2009.

FIGUEIREDO, J. L.; MENEZES, N. A. Manual de peixes marinhos do Sudeste do Brasil: teleostei, 1. São Paulo: MZ/USP, 1978. $110 \mathrm{p}$.

FIGUEIREDO, J. L.; MENEZES, N. A. Manual de peixes marinhos do Sudeste do Brasil: teleostei, 2. São Paulo: MZ/USP, 1980. 90 p.

GASALLA, M. A.; SOARES, L. S. H. Comentários sobre os estudos tróficos de peixes marinhos no processo histórico da ciência pesqueira e modelagem ecológica. Bol. Inst. Pesca, v. 27, n. 2, p. 243-259, 2001.

GROENEWALD, A. A. V. J. Observations on the food habits of Clarias gariepinus Burchell, the South African freshwater barbel (Pisces: Clariidae) in Transvaal. Hydrobiologia, v. 23, p. 287-291, 1964.
HERREL, A.; VAN WASSENBERGH S.; WOUTERS S.; ADRIAENS D.; AERTS P. A functional morphological approach to the scaling of the feeding system of the African catfish, Clarias gariepinus. J. Exp. Biol., v. 208, pt. 11, p. 2091-2102, 2005.

HYSLOP, E. J. Stomach content analysis: a review of methods and their application. J. Fish Biol., v. 17, p. 411-429, 1980.

KREBS, C. J. Ecological methodology. 2.ed. Menlo Park: Harlow: Benjamin/Cumining, 1999. 620 p.

LATINI, A. O.; PETRERE Jr., M. Reduction of a native fish fauna by alien species: an example from Brazilian freshwater tropical lakes. Fish. Manage. Ecol., v. 11, n. 2, p. 71-79, 2004.

LINTON, L. R.; DAVIES, R. W.; WRONA, F. J. Resource utilization indices: an assessment. J. Anim. Ecol., v. 50, n. 1, p. 283-292, 1981.

LODGE, D. M. Biological invasions: lessons for ecology. Trends Ecol. Evol., v. 8, n. 4, p. 133-137, 1993. [Review].

MACPHERSON, E. Resource partitioning in a mediterranean demersal fish community. Mar. Ecol.: Prog. Ser., v. 4, p. 183-193, 1981.

McKINNEY, M. L.; LOCKWOOD, J. L. Biotic homogenization: a few winners replacing many losers in the next mass extinction. Trends Ecol. Evol., v. 14, n. 11, p. 450-453, 1999.

MELO, G. A. S. Manual de identificação dos Brachyura (caranguejos e siris) do litoral do Brasil. São Paulo: Plêiade/ Fapesp, 1996. 604 p.

MENEZES, N. A.; FIGUEIREDO, J. L. Manual de peixes marinhos do Sudeste do Brasil: teleostei, 3. São Paulo: MZ/USP, 1980. 96 p.

MENEZES, N. A.; FIGUEIREDO, J. L. Manual de peixes marinhos do Sudeste do Brasil: teleostei, 4. São Paulo: MZ/USP, 1985. $105 \mathrm{p}$.

PEREIRA, M. D.; SIEGLE, E.; MIRANDA, L. B.; SCHETTINI, C. A. F. Hidrodinâmia e transporte de material particulado em suspensão sazonal em um estuário dominado por maré: Estuário de Caravelas (BA). Rev. Bras. Geofis., v. 28, n. 3, p. 427-444, 2010.

PINKAS, L.; OLIPHANT, M. S.; IVERSON, I. L. K. Food habits of albacore, bluefin tuna, and bonito in California waters. Sacramento: Department of Fish and Game, State of California 1971. 105 p. (Fish Bulletin; v. 152).

ROCHA, G. R. A. The introduction of the African catfish Clarias gariepinus (Burchell, 1822) into Brazilian inland waters: a growing threat. Neotrop. Ichthyol., v. 6, n. 4, p. 693-696, 2008.

SALA, E.; BALLESTEROS, E. Partitioning of space and food resources by three fish of the genus Diplodus (Sparidae) in a Mediterranean rocky infralittoral ecosystem. Mar. Ecol.: Prog. Ser., v. 152, n. 1/3, p. 273-283, 1997.

SCHETTINI, C. A. F.; PEREIRA, D. F.; SIEGLE, E.; MIRANDA, L. B. Hidrografia do estuário do Rio Itanhém, Bahia. In: CONGRESSO BRASILEIRO DE OCEANOGRAFIA, 3., 2008, Fortaleza. Anais. Fortaleza: Associação Brasileira de Oceanografia, 2008. CD-ROM 3.

SCHOENER, T. W. Resource partitioning in ecological communities. Science, v. 185, n. 4145, p. 27-39, 1974. 
SCHOENER, T. W. The anolis lizard of Bimini: resource partitioning in a complex fauna. Ecology, v. 49, n. 4, p. 704-726, 1968.

SCHOONBEE, H. J. Notes on the food habits of fish in Lake Barbespan. Western Transvaal, South Africa. Verh. Int. Limnol., v. 17, p. 689-701, 1969.

SCHULTZ, G. A. The marine isopod crustaceans. Dubuque: W. C. Brown, 1969. 359 p. (Pictured key nature series).

TEIXEIRA, R. L. Distribution and feeding habits of the young common snook, Centropomus undecimalis (Pisces: Centropomidae), in the shallow waters of a tropical Brazilian estuary. Bol. Mus. Biol. Mello Leitão, v. 6, p. 35-46, 1997.

TEUGELS, G. G. Preliminary results of a morphological study of five African species of the subgenus Clarias (Clarias) (Pisces; Clariidae). J. Nat. Hist., v. 16, n. 3, p. 439-464, 1982.

TONINI, W. C. T.; BRAGA, L. G. T.; VILA NOVA, D. L. D. Dieta de juvenis de Robalo Centropomus parallelus Poey, 1860 no sul da Bahia, Brasil. Bol. Inst. Pesca, v. 33, n. 1, p. 85-91, 2007.

VALIELA, I. Global coastal change. Malden: Blackwell, 2006. 368 p.

VITULE, J. R. S.; UMBRIA, S. C.; ARANHA, J. M. R. Introduction of the African catfish Clarias gariepinus (BURCHELL, 1822) into Southern Brazil. Biol. Invasions, v. 8, n. 4, p. 677-681, 2006.
WALLACE Jr., R. K. An assessment of diet overlap indexes. Trans. Am. Fish. Soc., v. 110, n. 1, p. 72-76, 1981.

WALLACE Jr., R. K.; RAMSEY, J. S. Reliability in measuring diet overlap. Can. J. Fish. Aquat. Sci., v. 40, n. 3, p. 347-351, 1983.

WILLIAMS, A. B. Shrimps, lobsters and crabs of the Atlantic Coast of the Eastern United States, Maine to Florida. Washington: Smithsonian Institution Press, 1984. $550 \mathrm{p}$.

YALÇIN, S.; AKYURT, I.; SOLAK, K. Certain reproductive characteristics of the catfish (Clarias gariepinus Burchell, 1822) living in the River Asi, (Turkey). Turk. J. Zool., v. 25, p. 453-460, 2001a.

YALÇIN, S.; AKYURT, I.; SOLAK, K. Stomach contents of catfish (Clarias gariepinus Burchell, 1822) in River Asi (Turkey). Turk. J. Zool., v. 25, p. 461-468, 2001 b.

ZARET, T. M.; PAINE, R. T. Species introduction in a tropical lake: a newly introduced piscivore can produce population changes in a wide range of trophic levels. Science, v. 182, n. 4111, p.449-455, 1973.

(Manuscript received 16 October 2012; revised 24 August 2013; accepted 02 June 2014) 